\title{
Substrate properties, forest structure and climate influences wood-inhabiting fungal diversity in broadleaved and mixed forests from Northeastern Romania
}

\author{
Ovidiu Copoț (Copot, Ovidiu) ${ }^{1^{*}}$ and Cătălin Tănase (Tănase, Cătălin) ${ }^{2}$ \\ ${ }^{1}$ Anastasie Fătu Botanical Garden, Alexandru Ioan Cuza University of Iaşi, 7-9 Dumbrava Roșie, 700487 Iaşi, Romania. ${ }^{2}$ Faculty of Biology, Alexandru \\ Ioan Cuza University of Iaşi, Carol I 20A, 700505 Iaşi, Romania.
}

\begin{abstract}
Aim of study: The main objective of this study was to find the factors which best explains the wood-inhabiting fungal species' richness in beech and oak-dominated forests.

Area of study: We focused on broadleaved and mixed forests found in Northeastern Romania.

Material and methods: 59 plots were randomly set up in broadleaved and mixed forest stands, in which vegetation structure, composition, and topoclimatic factors were quantified along with wood-inhabiting fungal richness. Generalized linear models were used to characterize the relationship between fungal diversity and biotic and abiotic factors.

Main results: 374 taxa were identified, with numerous species found to cohabitate, the highest sharing being between Fine Woody Debris and Downed Coarse Woody Debris. The best predictors of total diversity were related to the substrate, management, stand structure, and macroclimate. Higher volumes of logs and large branches in various decay stages increased fungal richness. The same effect was found in diverse forests, with large snags. Macroclimate and topoclimate positively influenced diversity, through De Martonne Aridity Index and snow cover length, both indicating macrofungi preferences for higher moisture of substrate. Silvicultural interventions had an ambivalent effect on fungal diversity, a phenomenon observed through stump numbers and proportion.

Research highlights: Particular environmental characteristics proved significantly important in explaining different wood-inhabiting fungal richness patterns. Substrate-related variables were the most common ones found, but they were closely linked to climate and forest stand variables.

Keywords: Wood-inhabiting fungi; oak, beech and coniferous forests; substrate diversity; dead wood types; coarse woody debris; fine woody debris; climatic variables.

Abbreviations used: ALT, elevation; ASPI, Aspect Index; BIO1, mean annual temperature; BIO4, temperature seasonality; BIO7, annual temperature range; BIO12, annual precipitation; BIO15, precipitation seasonality; CWD, coarse woody debris; $\mathrm{DBH}$, diameter at breast height; DCWD, downed coarse woody debris; DCWD_DECAY, DCWD decay diversity; DCWD_DIV, DCWD taxonomic diversity; DCWD_SV, surface-volume ratio of DCWD; DCWD_VOL, DCWD volume; DMAI, De Martonne Aridity Index; DMAI_AU, Autumn DMAI; DMAI_SP, Spring DMAI; DMAI_SU, Summer DMAI; DMAI_WI, Winter DMAI; FAI, Forestry Aridity Index; FWD, fine woody debris; L_SNAG_BA, large snag basal area; OLD_BA, basal area of old trees; POI, Positive Openness Index; RAI, Recent Activity Index; SCL, snow cover length; SLOPE, slope; SNAG_N, snag density; STUMP_N, stump density; TPI, Topographic Position Index; TREE_BA, mean basal area of trees; TREE_DIV, tree' Shannon diversity.

Authors' contributions: $\mathrm{OC}$ and CT conceived the idea and structure of the article, and identified the species; OC made field investigations, statistical analysis and graphical representation, and wrote the draft versions of the manuscript; CT supervised the work and revised different manuscript drafts, including the final one.

Citation: Copoț, O., Tănase, C. (2020). Substrate properties, forest structure and climate influences wood-inhabiting fungal diversity in broadleaved and mixed forests from Northeastern Romania. Forest Systems, Volume 29, Issue 3, e021. https://doi.org/10.5424/fs/202029316728 .

Supplementary material: Tables S1 to S3 accompany the paper on FS's website.

Received: 23 Mar 2020. Accepted: 29 Dec 2020.

Copyright (1) 2020 INIA. This is an open access article distributed under the terms of the Creative Commons Attribution 4.0 International (CC-by 4.0) License.

Funding: The authors received no specific funding for this work.

Competing interests: The authors have declared that no competing interests exist.

Correspondence should be addressed to Ovidiu Copoț: ovidiu.copot@uaic.ro
\end{abstract}

\section{Introduction}

Temperate broadleaved forests are home to a great diversity world-wide. Unfortunately, those forests are seve- rely disturbed at the global and continental scale (Nordén et al., 2004). A significant proportion of European broadleaved forests were transformed in the last 8,000 years by farmland activities and other land use (Fyfe et al., 2015). 
Most of the current European beech forests have a simplified structure and composition (Abrego \& Salcedo, 2011), the traditional way of wood extraction (Abrego \& Salcedo, 2011) or the modern forestry practices (Nordén et al., 2004) causing the depletion of coarse woody debris (CWD) - an important naturalness criterion and biodiversity indicator (Unar et al., 2017). This is the main reason for the threatening status of saproxylic fungi in Europe (Preikša et al., 2015), organisms playing a key role in forest biodiversity (Abrego \& Salcedo, 2011) as major wood decomposers (Kubart et al., 2016).

Substrate plays the most important role in explaining wood-inhabiting fungal richness patterns, through variate wood-related characteristics: dimension, species, type and complexity, decay stage, and microclimatic conditions (Bässler et al., 2010; Copoț et al., 2018; Heilmann-Clausen \& Christensen, 2003; Hottola \& Siitonen, 2008; Kubart et al., 2016; Runnel \& Lõhmus, 2017; Sefidi \& Etemad, 2015). Other biotic characteristics such as stand age, type, composition, richness, fragmentation or particular host trees species were also found important (Buée et al., 2011; Copoț \& Tănase, 2019; Dvořák et al., 2017; Runnel \& Lõhmus, 2017). Abiotic factors related to climate and soil are also known (Copoț et al., 2018; Tedersoo et al., 2015).

The most important factors influencing wood-inhabiting fungal diversity are frequently linked to the substrate, therefore a large part of the research is focusing on dead wood that can physically support the most fungi species - CWD, represented by logs (Heilmann-Clausen \& Christensen, 2003; Sefidi \& Etemad, 2015), stumps (Kubart et al., 2016) and snags (Enrong et al., 2006). Very fine or fine woody debris (FWD) are often overlooked, even if they may also be valuable for biodiversity (Nordén et al., 2004), in some cases, the FWD fungal richness being similar to CWD one (Bässler et al., 2010). Both types of woody debris have been found in relation to climate characteristics, as they are correlated with available moisture and temperature (Woodall \& Liknes, 2008).

Added to the biotic-climatic background, topography-related conditions referring to water availability and solar radiation can have multiple effects on the vegetation structure and forest community composition (Méndez-Toribio et al., 2016). Complex relationships between forest structure and composition and soil-related characteristics have been highlighted as strongly influencing the fungal communities (Kutsegi et al., 2015).

Most of the papers dealing with relationships between wood-inhabiting fungal diversity - environmental drivers have been conducted in Europe, North America and Eastern Asia (Abrego \& Salcedo, 2011; Bässler et al., 2010; Buée et al., 2011; Dvorák et al., 2017; Heilmann-Clausen \& Christensen, 2003; Hottola \& Siitonen, 2008; Kubart et al., 2016; Ódor et al., 2006; Sefidi \& Etemad, 2015). To our knowledge, few studies on a local scale (Bîrsan et al., 2014) or regional one (Copoț et al., 2018; Copoț \& Tăna- se, 2019) have been published investigating the relations between wood-inhabiting macrofungal diversity and environmental predictors, in the broadleaved forests of Northeastern Romania, with emphasis on complex fungal-forest-topography links.

The aims of this work were to answer the following questions: (1) Which are the most important factors driving the wood-inhabiting macrofungal species richness in forest ecosystems from NE Romania? (2) Are there differences in factors explaining fine versus coarse woody debris fungal species richness? (3) Does management influences wood-inhabiting fungal diversity?

\section{Materials and Methods}

\section{Study area}

The study area is located in the north-eastern part of Romania (Fig. 1), covering approximately $36,488 \mathrm{~km}^{2}$ (Eurostat, 2019) and, with the 12,122 $\mathrm{km}^{2}$ of forest across, it is one of the most forested regions of Romania (Andronache et al., 2017). The climate is temperate continental with mean annual temperature from $4^{\circ} \mathrm{C}$ to $11^{\circ} \mathrm{C}$, and mean annual precipitations in the range of 1,000 to 600 $\mathrm{mm}$, from higher to lower altitudes (ANM, 2008). The variety of landforms, edaphic, and climatic conditions influences, both on vertical and horizontal geographic spatial levels, the distribution of vegetation in Romania (Feurdean et al., 2007), with forest-geographic distribution effects including altitudinal and latitudinal zonation in the Northeastern part of the country.

The study was focused on the broadleaved and mixed forests in the North-East Region of Romania. A large part of them is edified by the most important European broadleaf tree species - European beech (Fagus sylvatica L.) (Petritan et al., 2012), also known in Romania as one of the most important forest species (Milescu et al., 1967). Other forests are instead dominated by the economically and ecologically important species of Quercus spp., especially pedunculate oak (Quercus robur L.) and oak (Quercus petraea (Matt.) Liebl.), which can also edify mixed stands with beech (Petritan et al., 2012). Oak species and beech are the main Central European broadleaved tree species (Schall \& Ammer, 2013) and forms most of the broadleaved forests in the region.

\section{Environmental variables}

In order to find which variables influence the wood-inhabiting fungal diversity in the study area, we considered various environmental characteristics, of climatic, topographic, forestry origin. Using SRTM DEM at 1 arcsec resolution (downloaded from USGS database), altitude 


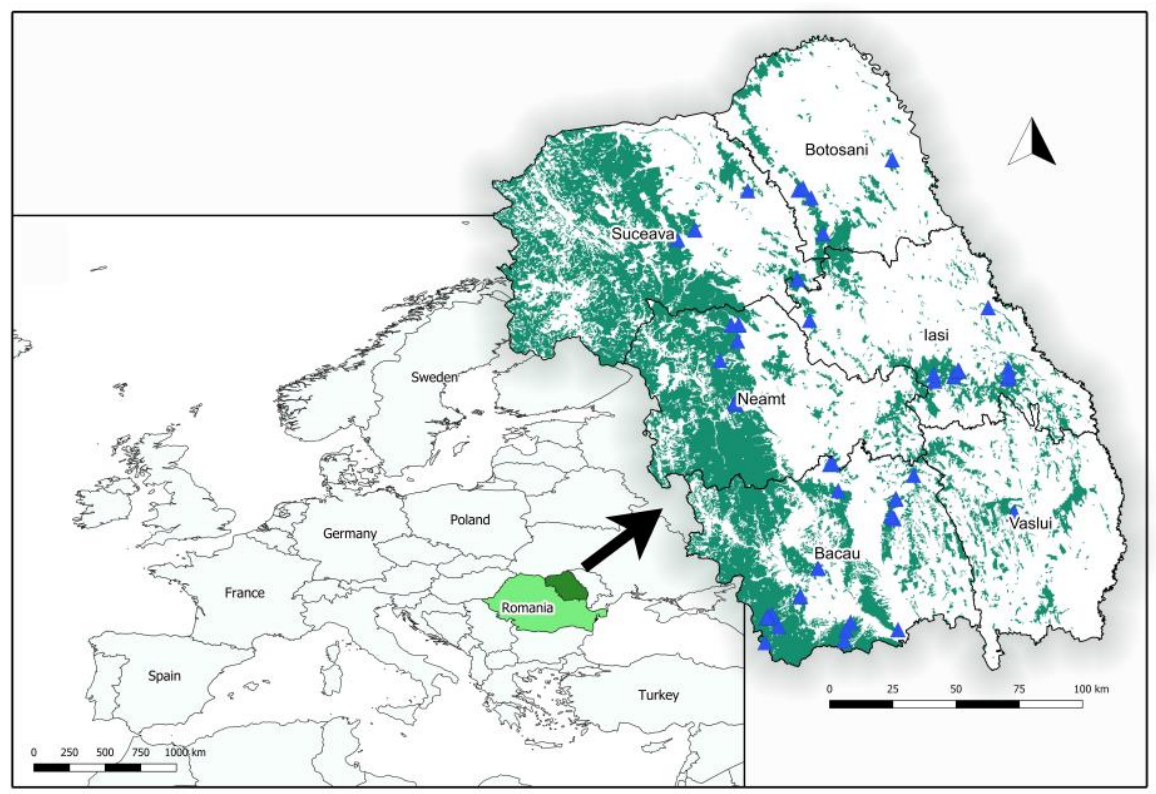

Figure 1. The distribution of plots in Northeastern Romania within the European context. The forest cover is depicted in green color and was obtained after Corine Land Cover 2018 version 20 raster (https://land.copernicus.eu/pan-european/corine-land-cover/ clc2018?tab=download).

was used (ALT) as well as elevation-derived geomorphometric variables calculated within SAGA GIS software (Conrad et al., 2015): Aspect Index (ASPI), slope (SLOPE), Topographic Position Index (TPI) and Positive Openness Index (POI). The last two defines the degree of plot enclosure by topographical features. Climatic variables were downloaded from WorldClim version 2.0 database, at the finest resolution -30 arcsec, or approximately $1 \mathrm{~km}$ (Fick \& Hijmans, 2017). The temperature-related variables were mean annual temperature (BIO1), temperature seasonality (BIO4) and annual temperature range (BIO7), while the precipitations-related were annual precipitations (BIO12) and precipitation seasonality (BIO15). Snow cover length (SCL) was downloaded from Lifewatch-WB ecotope database (Lifewatch Belgium, 2019), at $500 \mathrm{~m}$ resolution. De Martonne Aridity indexes - annual (DMAI), of spring season (DMAI_SP), summer (DMAI_SU), autumn (DMAI_AU) or winter (DMAI_WI), representing water balance variables and Forestry Aridity Index (FAI), as a climatic-tree growth index were calculated using WorldClim rasters (Führer et al., 2011; Quan et al., 2013).

\section{Structural and compositional forest stand variables}

A total of 59 circular plots of $1,000 \mathrm{~m}^{2}$ were randomly selected across the North-East Region's broadleaved and mixed forests. Within each sample plot, all standing trees (living and dead standing trees) with a diameter at breast height $(\mathrm{DBH}) \geq 10 \mathrm{~cm}$ were measured and taxonomically identified. For all living trees within the plot, mean basal area was calculated (TREE_BA). To each tree was assigned a size class, using the thresholds of 25 and $50 \mathrm{~cm}$. Total tree basal area (TREE_BA) and Shannon diversity of trees with $\mathrm{DBH}>25 \mathrm{~cm}$ were calculated for each plot (TREE_DIV).

The lying woody debris consisted of fine woody debris - FWD (pieces with diameter $>1 \mathrm{~cm}$ and $<10 \mathrm{~cm}$ ) and downed coarse woody debris - DCWD (pieces with diameter $\geq 10 \mathrm{~cm}$ ), according to Abrego \& Salcedo (2011). Fine woody debris were counted along four perpendicular linear transects of $11.2 \mathrm{~m}$, starting from the plot center and moving towards the cardinal directions.

Lying coarse woody debris (logs and large fallen branches) were all counted in plots, and for each of them, the decay stage, diameter at both ends and length were determined. Cut and natural stumps were considered as standing dead trees up to $1.3 \mathrm{~m}$ height and with an upper diameter $\geq 10 \mathrm{~cm}$. Stump, upper diameter, decay stage, and height were determined. Over $1.3 \mathrm{~m}$ height, dead standing wood was typed as snag and diameter at breast height (DBH) and decay stage were measured. All woody debris were taxonomically identified.

The decay stage was assigned for each dead wood piece using a 3 stages classification. For logs, the classification in Copoț \& Tănase (2019) was used. Snag decay classification is an adaptation after Tavankar et al. (2014): (i) incipient stage - intact top, minor losses or intact bark, majority of twigs present; (ii) intermediary stage - top in fragmentation process, scarce bark, twigs absent, less than $50 \%$ coarse branches left; (iii) advanced - broken top, no 
bark and branches, wood partially soft. Stump decay classification is an adaptation after Lombardi et al. (2013): (i) incipient - bark intact or partially present, wood with structural integrity, original color present; (ii) intermediate - absent bark, soften starting wood with easily disintegrating outer layers, original color fading; (iii) advanced - absent bark, soft texture, part of wood partially mixed in the forest soil, bryophytes and vegetation covers an important part of the stump.

To characterize mature forests, a specific variable (OLD_BA) was created that defines the large trees total basal area per plot (defined as trees with $\mathrm{DBH}>50$ $\mathrm{cm})$. DCWD taxonomic and DCWD decay diversities (DCWD_DIV, respectively DCWD_DECAY) were calculated according to Runnel \& Lõ ${ }^{-}$mus (2017). Snags were represented through a total large snag basal area variable (L_SNAG_BA) and snag density (SNAG_N). DCWD volume (DCWD_VOL) and surface to volume ratio (DCWD_SV) was calculated for DCWD, in order to represent the colonizing probabilities of wood-inhabiting fungi. Fine woody debris and stump substrates were represented through FWD numbers (FWD) and stump density (STUMP_N). For management intensity, Recent Activity Index (RAI) was calculated as the ratio between the number of stumps recently cut, and the total number of stumps cut. It ranged from 0 to 1 , where a value of 0 means that there is no activity in the area (no recent stumps), while increasing the values, means that more trees were cut in the present than in the past, and the activity intensity is increasing. Also, stump density was calculated (STUMP_N). Senescent trees were represented through old trees basal area for trees with DBH $>50$ cm (OLD_BA). Data about all variables is shown in Table 1.

\section{Fungal data}

Fungal diversity (richness) was assessed in a larger and concentric plot of $2,000 \mathrm{~m}^{2}$. Fungal inventories were conducted on at least three times at all sites, from spring to autumn of 2018. The field trips were realized in a time-frame of two weeks in order to benefit from homogeneous humidity conditions. Because of large geographic distances, extra surveys (maximum two) were made. For each plot, all woody debris were inventoried for sporomes. The collected fruitbodies were identified at species or genera level, either on-site or in the laboratory, using literature (Ellis \& Everhart, 1966; Ryvarden, 1976; Breitenbach \& Kränzlin, 1986; Ryvarden, 1991; Ryvarden \& Gilbertson, 1994; Bernicchia, 2005; Tănase et al., 2009; Courtecuisse \& Duhem, 2013). The fungal nomenclature was based on Index Fungorum (2019). After drying in air-vented ovens at $30^{\circ} \mathrm{C}$ for 72 hours, voucher specimens were deposited at the herbarium of Faculty of Biology, Alexandru Ioan Cuza University (Romania).

\section{Data analysis}

We used one set of environmental variables in order to identify the main drivers of fungal species richness. In order to reduce the variable collinearity, we used Pearson correlation $|r|>0.7$ as a cut-off threshold to determine the proper variables used in further analysis. The final set included two forest stand-related variables, one for management influence, three topoclimatic variables, three macroclimatic ones, and eight for the substrate.

Relationships among fungal richness and biotic, climatic and topographic variables were assessed in generalized linear models (Poisson probability of distribution). Selection of the best models was made according to Burnham \& Anderson (2002), (Table S1 [suppl.]). If overdispersion was detected, the negative binomial distribution of errors was assumed.

The important variables were selected according to $>0.5$ threshold (each of this variable was included in at least half of the total number of models constructed from all variables), (Table S2 [suppl.]). Significantly correlated predictors with species richness in linear models were explained in the discussions.

All statistical analyses were carried out using version 3.5.1 of the statistical programming environment $\mathrm{R}$ (R Core Team, 2018) by applying packages base, AER, MASS, MuMIn, reshape, and rsq. For graphical representation, we used R packages ggplot2, RcolorBrewer, and VennDiagram.

\section{Results}

\section{Taxonomic diversity}

We recorded a total of 374 fungal taxa (ca. 4,600 records on ca. 2,800 wood pieces) in forest ecosystems dominated by beech or oak from Northeastern Romania (Table S3 [suppl.]). The species belonged to 197 genera, 82 families, 30 orders and 2 phyla. Most of the species belong to Basidiomycota phylum (83.9\%), while the remaining to Ascomycota (16.1\%).

The number of total wood-inhabiting fungal species/ plot varied from 18 to 73 , with a mean of approximately 46 species. The woody debris types with the highest number of species were CWD with 305 taxa $(81.5 \%$ of total diversity), while on FWD were found 242 taxa (64.7\% of total diversity). Within CWD fraction, DCWD harbored 232 taxa (76.1\% of CWD diversity), stumps 198 taxa (64.9\%), and snags 72 taxa (23.6\%). Other wood types 
Table 1. Descriptive statistics of the environmental variables influencing fungal species diversity

\begin{tabular}{|c|c|c|c|c|}
\hline Environmental variable & Description & Unit & $\begin{array}{l}\text { Mean (Standard } \\
\text { Deviation) }\end{array}$ & Range \\
\hline \multicolumn{5}{|c|}{ Tree' stand structure and composition } \\
\hline TREE_DIV & Tree' Shannon diversity & - & $0.98( \pm 0.42)$ & $0-1.67$ \\
\hline TREE_BA & Mean basal area of trees & $\mathrm{m}^{2}$ & $0.13( \pm 0.06)$ & $0.04-0.30$ \\
\hline OLD_BA & Basal area of old trees & $\mathrm{m}^{2}$ & $19.02( \pm 15.66)$ & $0-53.7$ \\
\hline \multicolumn{5}{|l|}{ Management } \\
\hline RAI & Recent Activity Index & - & $0.31( \pm 0.33)$ & $0-1$ \\
\hline \multicolumn{5}{|l|}{ Dead wood } \\
\hline FWD & Number of FWD pieces & - & $29( \pm 10.76)$ & $14-63$ \\
\hline DCWD_SV & Surface-volume ratio of DCWD & $\mathrm{m}^{2} / \mathrm{m}^{3}$ & $22.5( \pm 12.17)$ & $0-44.36$ \\
\hline DCWD_DIV & DCWD taxonomic diversity & - & $0.22( \pm 0.32)$ & $0-1.08$ \\
\hline DCWD_DECAY & DCWD decay diversity & - & $0.30( \pm 0.33)$ & $0-0.98$ \\
\hline DCWD_VOL & DCWD volume & $\mathrm{m}^{3} / \mathrm{ha}$ & $11.79( \pm 24.39)$ & $0-148.9$ \\
\hline L_SNAG_BA & Large snag basal area & $\mathrm{m}^{2} / \mathrm{ha}$ & $1.75( \pm 2.90)$ & $0-14.30$ \\
\hline SNAG_N & Snag density & $\mathrm{ha}^{-1}$ & $19.49( \pm 22.08)$ & $0-120$ \\
\hline STUMP_N & Stump density & $\mathrm{ha}^{-1}$ & $44,7( \pm 37.46)$ & $0-190$ \\
\hline \multicolumn{5}{|l|}{ Topoclimate } \\
\hline ALT & Elevation & $\mathrm{m}$ & $392.9( \pm 149.1)$ & $81-706$ \\
\hline ASPI & Aspect Index & - & $82.94( \pm 49.03)$ & $2.44-174.29$ \\
\hline SLOPE & Slope & $\circ$ & $10.2( \pm 7.26)$ & $0.7-30.4$ \\
\hline POI & Positive Openness Index & - & $1.46( \pm 0.07)$ & $1.17-1.57$ \\
\hline TPI & Topographic Position Index & - & $-5.6( \pm 58.25)$ & $-189.4-172.3$ \\
\hline \multicolumn{5}{|l|}{ Macroclimate } \\
\hline SCL & Snow cover length & weeks & $10( \pm 4)$ & $3-18$ \\
\hline DMAI & De Martonne Aridity Index (annual) & $\mathrm{mm} /{ }^{\circ} \mathrm{C}$ & $48.4( \pm 2.9)$ & $42.3-55.2$ \\
\hline DMAI_SP & Spring De Martonne Aridity Index & $\mathrm{mm} /{ }^{\circ} \mathrm{C}$ & $16.6( \pm 1.9)$ & $14.1-21.5$ \\
\hline DMAI_SU & Summer De Martonne Aridity Index & $\mathrm{mm} /{ }^{\circ} \mathrm{C}$ & $14.4( \pm 1.6)$ & $11.5-17.9$ \\
\hline DMAI_AU & Autumn De Martonne Aridity Index & $\mathrm{mm} /{ }^{\circ} \mathrm{C}$ & $12.0( \pm 0.6)$ & $11.0-13.4$ \\
\hline DMAI_WI & Winter De Martonne Aridity Index & $\mathrm{mm} /{ }^{\circ} \mathrm{C}$ & $58.5( \pm 11.8)$ & $36.4-102.2$ \\
\hline FAI & Forestry Aridity Index & ${ }^{\circ} \mathrm{C} / \mathrm{mm}$ & $4.98( \pm 0.59)$ & $3.9-6.1$ \\
\hline BIO1 & Annual mean temperature & ${ }^{\circ} \mathrm{C}$ & $8.43( \pm 0.73)$ & $6.70-9.50$ \\
\hline $\mathrm{BIO} 4$ & Temperature seasonality & $\%$ & $8.16( \pm 0.339)$ & 7.4-8.6 \\
\hline $\mathrm{BIO} 7$ & Annual temperature range & ${ }^{\circ} \mathrm{C}$ & $30.28( \pm 1.42)$ & $26.9-33.3$ \\
\hline $\mathrm{BIO} 12$ & Annual precipitation & $\mathrm{mm}$ & $559.7( \pm 19.27)$ & $523-605$ \\
\hline $\mathrm{BIO} 15$ & Precipitation seasonality & $\%$ & $49.53( \pm 5.15)$ & $40-58.9$ \\
\hline
\end{tabular}

(dead and living roots, buried woody fragments) harbored only 17 taxa.

Fungal records varied among wood types, as FWD and stumps counted the most (ca. 2,200, respectively 1,100 records). At plot level, a mean of 1.9 species per log/large branch, 1.9 species per snag, and 2.3 species per stump were registered. Overall, there were 2.1 species per CWD piece and 1.3 species per FWD piece.

Taxa found in more than $3 / 4$ rd of plots were: Stereum hirsutum, Diatrype stigma and Exidia glandulosa. Most frequent species found on CWD (more than 24 plots) were both ascomycetes: Xylaria polymorpha, Kretzschmaria deusta, Jackrogersella cohaerens, Mollisia spp. and basidiomycetes: Stereum hirsutum, Bjerkandera adusta, Trametes versicolor, Hymenopellis radicata, Fomes fomentarius, Pluteus cervinus and Hymenochaete rubiginosa. On FWD, the most frequent species where ascomycetes: Diatrypella agg., Diatrype stigma, D. disciformis, Hypoxylon fragiforme, Biscogniauxia nummularia and basidiomycetes: S. hirsutum, E. glandulosa, Schizophyllum 
commune, Peniophora quercina, Marasmius rotula, Vuilleminia comedens.

In the studied forests, 105 fungal species were found only once (defined as rare species), representing approximately $27.1 \%$ of species richness, while 47 species were found twice (12.5\%).

Generally, fungal species colonized more than one type of woody debris. FWD was highlighted as the most species-rich type of woody debris. FWD-specific richness represented approximately $15 \%$ of total diversity and $23.5 \%$ of FWD diversity. Stumps and DCWD harbored alone approximately the same numbers of species, which represented 9.3-10.1\% of total diversity. Snags harbored the lowest number of wood-specific species $(0.5 \%$ of total diversity).

The greatest shared number of species was between FWD and DCWD, with $41.9 \%$ of total diversity, followed by stump-DCWD (35.3\%) and stump-FWD (33.2\%). On all types of woody debris, were found 34 species $(9.1 \%$ of total diversity). A large proportion of species colonizing snags was also found on stumps (76.4\%), DCWD (73.6\%), and FWD (72.2\%). Still, only 9.7\%, 5.6\%, and $6.9 \%$ of snag species were found only on stumps, FWD, and DCWD, the rest being shared between all four WD types.

\section{Predictors of fungal species richness}

Total diversity was significantly and positively correlated with FWD diversity $(0.63, p<0.0001)$ and CWD diversity $(0.76, p<0.0001)$. For total diversity variation, eight variables were found to be important and significant (Table 2). For CWD, eight out of nine variables were found to be important and significant, while for FWD diversity four out of six (Table 2). Dead wood stand-related characteristics were found frequently among significant and important predictors: DCWD diversity (total and CWD diversities), surface-volume ratio (total and CWD diversities), DCWD volume (total and CWD diversities), and FWD (total and FWD diversities).

Tree-related characteristics were also important: tree diversity (FWD diversity) and large snags (total and CWD diversities). Autumn DMAI (all diversities) and snow cover length (CWD diversity) were also important macroclimatic characteristics. Found predictors showed a relatively complex relation in terms of diversity on different substrates. Among the important variables, only the number of stumps, and RAI, had negative effects (Fig. 2: B, R). Autumn DMAI was positively correlated with Spring DMAI $(0.77, p<0.0001)$, Winter DMAI $(0.75, p<0.0001)$ and Annual DMAI (0.81, $p<0.0001)$, annual precipitations $(0.80, p<0.0001)$, and negative correlated with mean annual temperature $(-0.71$, $p<0.0001$ ).

\section{Discussion}

\section{Substrate}

In our study, snags have been found important for total and CWD fungal richness. An increase of large snag basal area also increases CWD diversity (Fig. 2: P), while an increase of large snags basal area also increases total diversity (Fig. 2: H). In forests, snags are considered important habitats for numerous wildlife species (Holloway et al., 2007; Perry \& Thill, 2013), including wood-inhabiting fungi.

Snags' probability of standing decreases with time and increases with $\mathrm{DBH}$, both for coniferous and hardwoods, in temperate mixed forests (Perry \& Thill, 2013). This means that in a stand with a high large snags basal area, snags could stand for a longer period of time (Tavankar et al., 2017). Dead large standing trees are the main DCWD input sources (Gora et al., 2014). As a consequence of longer snag life, snags constantly output less-decayed wood, thus maintaining a balance between DCWD decay stages (Tavankar et al., 2017). In our study, high DCWD decay diversity has been found to positively influence fungal richness on CWD (Fig. 2: M).

As the snag decay advances, larger pieces will fall to the ground (Holloway et al., 2007), and the close-snag downed wood-pool will change its total volume and WD type proportions, from FWD to large logs. Initially, a small number of FWD-associated fungi will develop, but, with time, more fungal species that need larger resources will colonize on the increased size of fallen dead wood. Our study showed that a large proportion of FWD-associated species also grows on DCWD, which means that even if FWD volume will decrease, logs and large branches will function as a substitute substrate for a large proportion of FWD fungal species. Thus, as the snag is decaying, the total fungal diversity is increasing.

In our study, total and DCWD-associated richness increases with the total DCWD volume (Fig. 2: F, O). Numerous studies confirmed the strong relationship between dead wood volume and wood-inhabiting fungal richness (Copoț \& Tănase, 2019; Klockow et al., 2014; Heilmann-Clausen \& Christensen, 2004; Runnel \& Lõhmus, 2017). Besides nutrients and space availability for mycelial development, increased DCWD volume can be associated with larger or numerous logs, in diverse decay stages, thus increasing ecological niches numbers. Old-growth or natural forests are often defined through large dead wood volume (Wirth et al., 2009). In turn, those forests are home to numerous species of macrofungi from all trophic groups including saproxylic ones (Dvořák et al., 2017; Wirth et al., 2009).

In our study, substrate diversity plays an important role for fungal richness. Stands with higher tree richness hosts great FWD-inhabiting fungi richness (Fig. 2: T). 
A

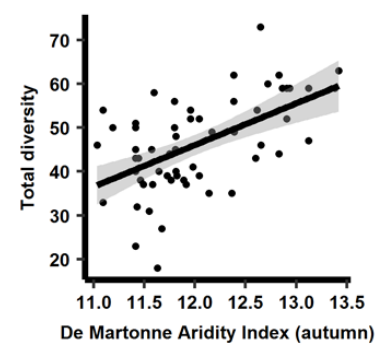

E

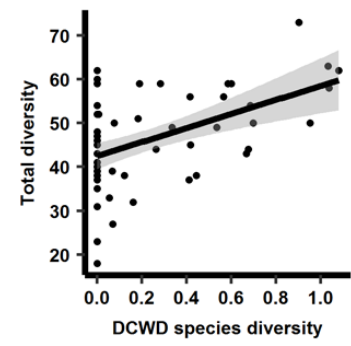

I

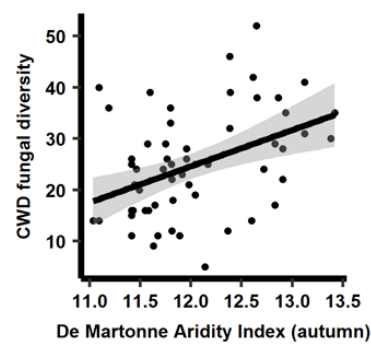

M

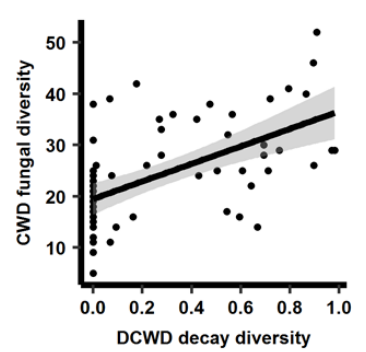

Q

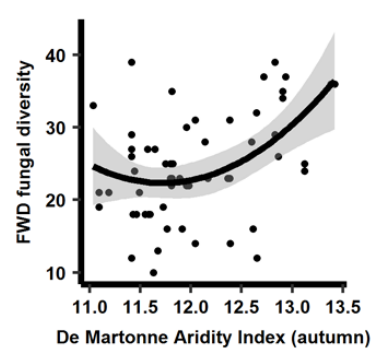

B

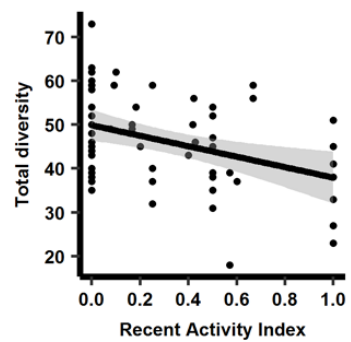

$\mathbf{F}$

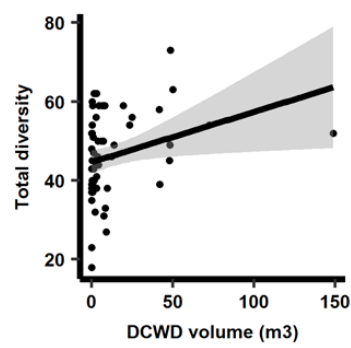

$J$

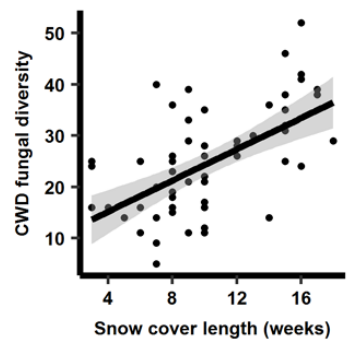

$\mathbf{N}$

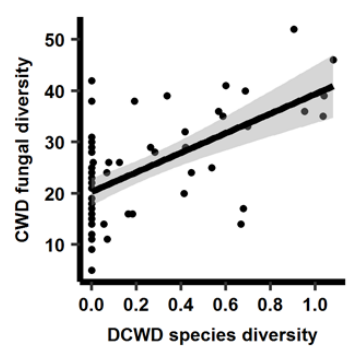

$\mathbf{R}$

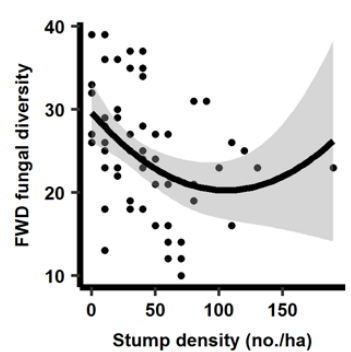

C

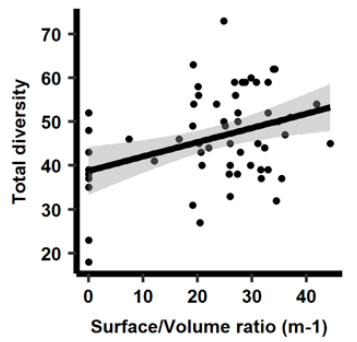

G

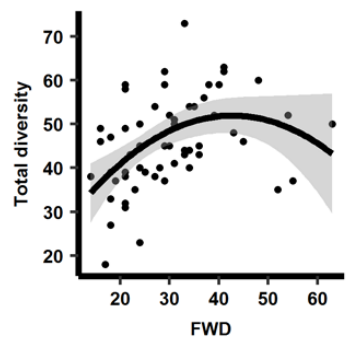

K

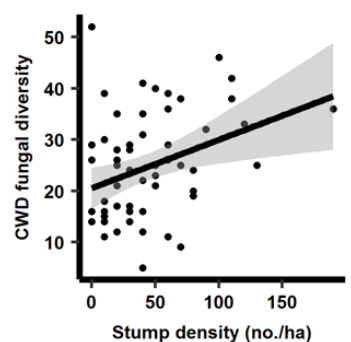

O

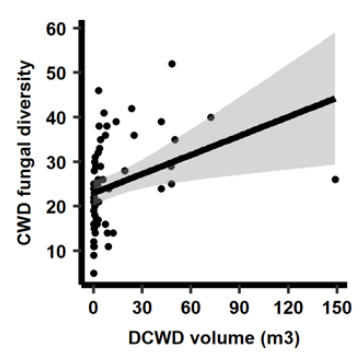

S

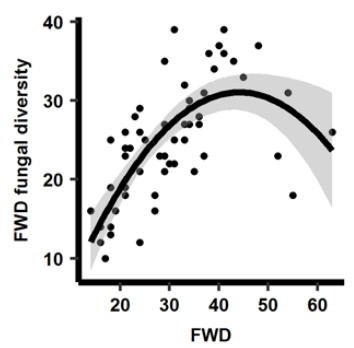

D

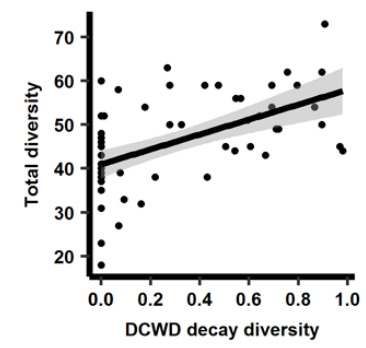

H

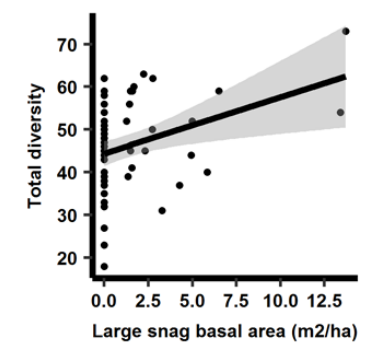

$\mathbf{L}$

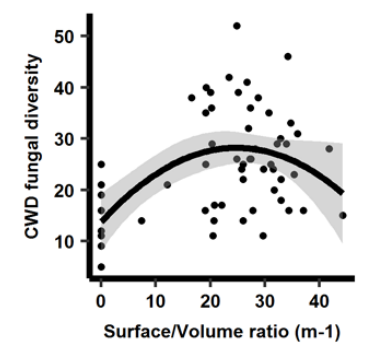

$\mathbf{P}$

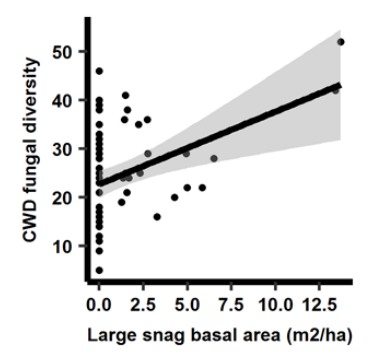

T

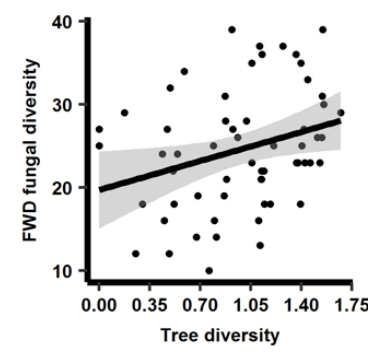

Figure 2. Graphic representation of the relations between environmental predictors and wood-inhabiting fungal diversity. Graphics from A to $\mathrm{H}$ represents the relationships between macrofungal total richness and variables of macroclimate, dead wood and forest management; from I to P, between the number of macrofungi found on CWD and variables of macroclimate, dead wood and human influence; from $Q$ to $T$, between FWD-associated fungi and macroclimate, dead wood, forest management, and forest structure 
Table 2. Linear models highlighting the effect of selected predictors on total fungal species richness, on CWD and FWD associated fungal richness

\begin{tabular}{lccc}
\hline \multicolumn{1}{c}{ Variable } & $\begin{array}{c}\text { Coefficient } \\
\text { Estimate }\end{array}$ & $\begin{array}{c}\text { Standard } \\
\text { Error }\end{array}$ & P-value \\
\hline Total wood-inhabiting fungal diversity & & & \\
DCWD_DIV & 16.05 & 3.75 & $<0.0001$ \\
DMA__AU & 9.52 & 1.90 & $<0.0001$ \\
FWD & 0.34 & 0.12 & 0.0078 \\
RAI & -11.96 & 3.89 & 0.0033 \\
L_SNAG_BA & 1.30 & 0.45 & 0.006 \\
DCWD_SV & 0.33 & 0.11 & 0.0037 \\
DCWD_DECAY & 17.01 & 3.51 & $<0.0001$ \\
DCWD_VOL & 0.12 & 0.05 & 0.024 \\
CWD-associated wood-inhabiting fungal diversity & & & \\
L_SNAG_BA & 1.56 & 0.43 & $<0.0001$ \\
DCWD_SV & 0.32 & 0.11 & 0.0034 \\
DCWD_VOL & 0.14 & 0.05 & 0.0097 \\
DCWD_DECAY & 17.11 & 3.39 & $<0.0001$ \\
DCWD_DIV & 19.07 & 3.38 & $<0.0001$ \\
SCL & 1.52 & 0.29 & $<0.0001$ \\
DMAI_AU & 7.06 & 2.03 & $<0.0001$ \\
FWD-associated wood-inhabiting fungal diversity & & & \\
DMAI_AU & 4.56 & 1.44 & 0.0025 \\
FWD & 0.39 & 0.07 & $<0.0001$ \\
STUMP_N & -0.06 & 0.02 & 0.020 \\
TREE_DIV & 4.99 & 2.16 & 0.025 \\
\hline Vat_bs & & &
\end{tabular}

Variables abbreviations are explained in Table 1.

Also, a higher number of DCWD taxonomic diversity is positively influencing total and CWD fungal richness (Fig. 2: E, N). Tree species diversity has been found to positively influence wood-inhabiting fungi (Dvorák et al., 2017; Heilmann-Clausen et al., 2005), or, more particular, polypores (Runnel \& Lõhmus, 2017). In the same region, Copoț et al. (2018) observed higher fungal richness with increased continentality index in beech-dominated forests, which in turn was associated with thermophilous trees increasing presence and higher tree richness. This hypothesis must take into account the study conditions, as it took only climatic variables and the smaller fraction of FWD.

DCWD high diversity has been often related to wood-inhabiting fungal richness. Bîrsan et al. (2014) observed that high dead wood fungal diversity was related with high woody plants diversity, in Fagus, and Quercus-dominated forests from the northern part of our study region. Heilmann-Clausen et al. (2005) found at least a mean of 15 fungal species per log, for all five genera inventoried, all those genera were also found in our study.
In our study, numerous fungi occurring on stumps, FWD or snags were also found on logs and large branches. This shows the high colonization capacity of macrofungi and the importance of downed CWD in forests. Also, this means that a stand with numerous logs and large branches of different species might host a greater diversity of fungi, increasing CWD and total fungal richness, even if there are few stumps or standing dead trees. As numerous other studies confirmed (Heilmann-Clausen \& Christensen, 2003; Hottola \& Siitonen, 2008; Sefidi \& Etemad, 2015; Iršènaite \& Kutorga, 2006), DCWD represents the most valuable habitat for forest's wood-inhabiting fungal diversity conservation. In this context, DCWD characteristics might be of high importance for conservation management strategies.

In our study, the decay diversity of downed coarse woody is positively influencing total and CWD fungal richness (Fig. 2: D, M). The distribution of decay stages among forest plots is influencing fungal richness, as particular species are associated with certain decay stages (Heilmann-Clausen et al., 2005). Still, there might be 
differences depending on the tree species, as advanced decayed aspen logs had $9 \%$ more fungal richness than medium decayed ones (Kebli et al., 2012).

In our study, FWD numbers have been found to positively influence both total and FWD-associated fungal richness (Fig. 2: G, S). FWD importance for higher total richness might be derived from complex relations with the other types of woody debris. The large sharing of fungal species of other woody types with FWD clearly shows that fungi are capable to shift woody debris of different sizes, depending on wood habitable conditions. This might work as a great adaptation for some fungi, especially for cord-forming fungi.

Under species-specific conditions (from water stress and nutrient depletion to the presence of antagonistic fungi), some wood-inhabiting fungi are producing mycelial cords (Boddy, 1993). Cord-forming fungi like Hypholoma fasciculare, Megacollybia platyphylla, Phanerochaete velutina, Phlebia radiata, Steccherinum fimbriatum, Stereum gausapatum or T. versicolor, were also found in our study. Through cords, these species migrate, the main purpose being to find another water and nutrients source to colonize. The spreading distance varies from species to species, from under one meter to several hundred meters (Boddy, 1993).

In this context, dead wood connectivity might be critical for species establishment (Morrissey et al., 2014), as more dead wood pieces would facilitate colonization via litter, for more wood-inhabiting species. Therefore, a large number of FWD might increase the survival chances of wood-inhabiting fungi in the stand, especially for fungi that needs large resources. Also, the fact that total and CWD fungal richness increases with surface-volume ratio (Fig. 2: C, L) clearly shows the importance of smaller DCWD for fungal colonizing. A similar situation, of larger surface-volume ratio was found as the main reason for log complexity's positive influence on wood-inhabiting fungal diversity on beech logs (Heilmann-Clausen \& Christensen, 2003).

Also, an inverse relationship has been observed, as with increasing the FWD numbers, the total and FWD diversities decreased (Fig. 2: S, G). The main reason behind this might be the fine dead wood decay diversity. In forests with recent disturbances, like strong storms or selective cuttings, the number of FWD is increasing with fresh pieces. In a German forest, numerous fungi colonized canopy branches, the majority of them in the middle and lower canopy, while in the upper canopy, $60 \%$ of total records were dominated by species from only four genera (Unterseher et al., 2003). Thus, the new-fallen fine pieces - especially coming from the upper canopy, will have a lower fungal richness compared with undisturbed forest stands, where the FWD comes from all canopy levels.

Increasing surface-volume ratio past a certain value $\left(20 \mathrm{~m}^{2} / \mathrm{m}^{3}\right)$, decreases CWD fungal diversity (Fig. 2: L). In our study, the plots made in the Eastern Carpathians have similar surface/volume ratios to those in riverine plots found in Moldova Plateau, still their total diversity was higher, mostly because of the presence of coniferous substrate and longer periods with high humidity.

After snag disintegration on the forest floor, the log-fungal communities continue to develop, as logs communities were found to incorporate species typical to snag communities (Kebli et al., 2012). Also, species that were not able to develop earlier will colonize the wood after, spreading through the air (Coates \& Rayner, 1985) or soil and litter, increasing competition among fungi. Litter is known to contain large amounts of lignin (Paliwal et al., 2015) and various nutrients in quantities even larger than coarse woody debris (Balboa-Murias et al., 2006), which will furthermore favor mycelia migration. In relation to snag decaying, both FWD and DCWD accumulate on the forest floor, at shorter distances. Those dead wood accumulation places might function as important survival spots within forests, thus showing the high value of larger snags. Also, a greater large snag density would shorter the distances between dead wood accumulation places, increasing furthermore the wood-inhabiting fungal richness.

Another effect of cord-forming fungal migration between dead wood pieces is the nutrient translocation between the initial source and new-found source. Some of these nutrients are entering the new substrate, thus enriching it (Boddy, 1993). In conditions of higher substrate moisture (high DMAI_AU) and large amount of FWD and smaller DCWD, fungi with a greater migration capacity might have an important function in the forest mycodiversity. Dead wood accumulation spots might work as nutrient spreading sources, increasing furthermore survival of some fungi with lesser migrating capacity, that are in search of a substrate. Because cord-forming fungi have good competitive abilities when colonizing a new dead wood piece (Boddy, 1993), the previous fungal community will respond differently depending on its composition. Therefore, in stands with larger amounts of dead wood of different tree species and decay stages, the fungal richness might increase as a consequence of a larger fungal community variation.

\section{Climate}

In our study, increased values of Autumn De Martonne Aridity Index induced higher total, CWD and FWD fungal richness. This means that areas with higher precipitations reported to temperatures, or lower temperatures reported to precipitations, were more diverse in wood-inhabiting species. Also, the strong correlation between Autumn DMAI and annual precipitations, respectively mean annual temperature sustains the positive relation of fungal richness to the climatic factors.

Strong correlations between De Martonne AI for autumn and De Martonne AI for spring, and winter, shows 
that humidity during the cooler seasons might prove highly important for the survival of wood-inhabiting fungi. In cooler and wetter conditions, wood close to snags retains more moisture (Brazee et al., 2014). During spring and autumn, fungi are active fruiting bodies producers (Brazee et al., 2014). Still, there are differences in the distribution of precipitation at the regional scale, which can be observed through Autumn DMAI. Thus, our results sustain that those differences help explain the higher diversity in areas with higher precipitations and lower temperatures (Fig. 2: A, I, Q).

Low temperatures are inhibiting the decay process $(\mathrm{Ku}-$ bartová et al., 2009), which can extend the survival rate of woody debris, in multiple decay stages, which means that the probability of CWD in multiple decay stages to co-exist, increases. This climatic effect can be observed at multiple CWD type levels, as the standing time of snags increases in colder regions at the continental scale (Perry \& Thill, 2013), which involves the CWD differences shown before. This is in agreement with our findings, that a higher decay diversity increases fungal diversity. In addition, during autumn, fungal diversity is increasing in temperate regions (Rudolph et al., 2018), therefore, the higher the Autumn De Martonne Aridity Index is, the higher is the fungal diversity.

Because of the small dimensions, FWD maintains moisture for a shorter period of time (Berbeco et al., 2012). Therefore, FWD in a region with higher precipitations and lower temperatures, delineated here by higher values of Autumn DMAI, have better probabilities to maintain the water and allow mycelia to develop, without the risk of desiccation for long periods of time. This allows that other than drought-resistant species to develop on those branches, thus enriching the FWD diversity. On the other side, increasing Autumn DMAI decreases FWD fungal diversity, which is most probably a local effect caused by microclimatic variations. In our case, FWD fungal richness is higher in riverine oak-dominated forests, and decreases towards hilly oak forests, even if Autumn DMAI increases. In other words, the macroclimatic effects on fungal richness are diverse, depending on a variety of factors, including local topoclimatic characteristics (such as higher soil humidity, due to the upper water level).

Another climatic characteristic - snow cover length, positively influenced CWD fungal richness (Fig. 2: J). As it increases with elevation, towards mountain areas, snow lasts longer and it's thicker. In mountain areas, thanks to wind exposure and slope, the snow is redistributed to sheltered locations, which keeps snow longer and in a thicker layer (Grünewald et al., 2014). Valleys bottoms might have better humidity conditions (Copoț \& Tănase, 2019; Goia \& Gafta, 2018) thus functioning as refugia for some hydrophilic fungi, increasing overall diversity. Also, in the valley bottom, the beech-dominated forests start earlier the vegetation period (Milescu et al., 1967), which means that lying dead wood is earlier shadowed, keeping moisture for a longer period of time. In mountain forests, large forest gaps facilitate snow accumulation through snow releasing by upwind canopy flow (Roth \& Nolin, 2017). Consequently, it accumulates on snag's fallen woody debris, thus insulating and increasing wood humidity. After snow melting, the large downed dead wood maintains snow-resulted humidity for a longer period of time. As a consequence, fungi manage to produce carpophores, thus being able to favor particular fungal species, especially discomycetes during spring, which will rise DCWD fungal richness.

\section{Management}

In the current study, fungal richness is influenced by the intensity of forest management, estimated here through stump density, Recent Activity Index, and large snag basal area. Generally, both large snags and medium and advanced stage-decay stumps presence is associated in our plots with higher habitat availability and differentiation. Woody substrates decaying in time is associated with fungal community succession and species replacement, which means that in a plot with a high qualitative variation of substrates (dead wood in multiple decay stages), there are more fungal species. Therefore, forest management per se should not have a negative impact on fungal richness if a proper balance between different substrate qualities is maintained.

In some cases of negative influence of particular silvicultural practices, the downed CWD in medium and advanced decay stages is destroyed during tree extraction which lowers fungal richness (Rabinowitsch-Jokinen \& Vanha-Majamaa, 2010). Also, wood removal is highly associated with reducing highly specialized and endangered fungi numbers (Heilmann-Clausen \& Christensen, 2003). On the other side, proper silvicultural interventions as selective cuttings and partial removal of wood successfully maintains various substrates available for fungi to colonize. As a result of selective cutting, retention trees, and unharvested portions function as late successional providers (represented here through large snags and higher qualitative logs and stumps) for high diversity maintainers (Chaudhary et al., 2016). The fact that higher stump density per se - as a direct indicator, usually associated with decreasing dead-wood inhabiting mycodiversity can differentially influence the number of fungi due to its qualitative characteristics shows that forest management-induced environmental characteristics are a good indicator of management systems complex influence on biodiversity, at least in managed forests.

The presence of snags can also be considered as an indicator of low-intensity forest management, as numerous 
studies confirmed that high snag extraction was related to harvesting. In coniferous forests in north-western US snag density was three times lower in partially harvested stands, than in unharvested stands (Wisdom \& Bate, 2008). Infected dying or dead trees are usually extracted from managed stands, which does not allow to reach snag status and furthermore enrich DCWD pool. As a consequence, silvicultural practices reduce snag density (Hallett et al., 2001) and volume (Tavankar et al., 2017). Therefore, managed forests have lower quantities of snags and logs (Tavankar et al., 2017, Kebli et al., 2012), which in turn decreases forest wood-inhabiting fungal diversity (Dvořák et al., 2017; Heilmann-Clausen \& Christensen, 2003).

In the first part of the U-shaped relationship, the total number of stumps, as a measure of logging intensity (Sippola et al., 2004), has a negative influence on FWD fungal diversity in our study (Fig. 2: R). In a boreal forest, total diversity was not affected by logging intensity, but the number of records was (Sippola et al., 2004), which in turn was explicated through reduced substrate availability. In the second part, FWD diversity is increasing as the stump number also increases (Fig. 2: R). The right side of the relationship is rather a local effect of a disturbance, most probably induced by man, which increases stump and FWD numbers. So, this effect might be due to partial tree extraction, which is known to increase downed FWD numbers (Ostrogović et al., 2015), which in turn is related to FWD macrofungal richness increasing (Fig. 2: S).

CWD fungal richness is also increasing as stump density is higher (Fig. 2: K). Stumps are valuable coarse woody debris which hosts numerous species of fungi (Kubart et al., 2016), especially in managed forests, where it often represents most of CWD fraction (Kubart et al., 2016). This finding is also sustained by the fact that, from the total stump fungal diversity, $3 / 4$ were also found on other CWD wood types. According to the RAI relationship, increasing the number of relatively recent stumps decrease total diversity (Fig. 2: B) while increasing the total number of stumps, generates an opposite response of CWD fungal richness. In other words, is not the total number of stumps but rather the number of middle and advanced decayed stumps that positively influence the CWD fungal richness. This assumption is confirmed by some studies, as oak stumps hosted more wood-inhabiting fungal species as decay advanced (van der Wal et al., 2017). Related to forest management, other studies found that the wood-inhabiting fungal diversity constantly increases as the time since silvicultural interventions passed (Kebli et al., 2012).

\section{Study limitations and further study directions}

In this study, we focused specifically on environmental variables that characterize the climate (both the macro- climate and the microclimate) and substrate variability, both at quality and quantity levels. The fact that stump characteristics were found to influence the macrofungal richness, prone us to suggest a study on the effect of forest management type on wood-inhabiting fungal diversity. More forest management variables can be accounted in order to properly investigate and efficiently draw a conclusion about the effect of silvicultural practices on biodiversity sensu lato in managed forests.

As any fungal fruit bodies-based study, ours is limited by the short duration of the sampling period (1 year). Some studies report additional species of macrofungi after extended periods (Rudolph et al., 2018). Other authors emphasize the importance of multiple-months surveys for agaric species diversity and of multiple-years for polypore species diversity (Abrego et al., 2016). Still, for present-like studies, Abrego et al. (2016) recommend as enough one peak fruiting season for fungal data collection. Also, considering the exceptionally humid June of 2018, and the large amount and variety of substrates investigated, we were able to reduce the sampling handicap. Therefore, our results should be considered in their respective spatial and time limitations.

\section{Conclusions}

This is the first study in which the biotic and abiotic predictors explaining the variation of wood-inhabiting macrofungal diversity in broadleaf-dominated forests in Northeastern Romania were identified. For total fungal richness, forest diversity, dead wood characteristics, management, and climate variables proved the best predictors. This clearly shows the great importance of mature forests, with particular management influence. Woody debris, both standing and fallen, are the most important forest component for fungal survival. Both the quantity and diversity of available dead wood are associated with higher numbers of fungal species. Particular climatic conditions increase fungal diversity through higher substrate moisture, as it is an essential agent in mycelial growth. CWD and FWD fungal richness showed different responses to environmental variables, both being influenced by dead wood, climate, and logging. As a consequence, it is important to maintain those forests at a high level of naturalness, keeping enough amounts of dead wood, especially snags and logs, in order to protect the wood-inhabiting fungal diversity.

\section{Acknowledgements}

The authors wish to thank T. Balaeș, C. Bîrsan, A. Cojocariu, C.-V. Petre, and C. Mardari, for the help provided during the research. The authors thank the anonymous 
reviewers for their valuable comments and manuscript improvement help.

\section{References}

Abrego N, Salcedo I, 2011. How does fungal diversity change based on woody debris type? A case study in Northern Spain. Ekologija 57(3): 109-119. https://doi. org/10.6001/ekologija.v57i3.1916

AbregoN, Halme P, Purhonen J, Ovaskainen O, 2016. Fruit body based inventories in wood-inhabiting fungi: Should we replicate in space or time? Fungal Ecol 20: 225-232. https://doi.org/10.1016/j.funeco.2016.01.007

Administrația Națională de Meteorologie, 2008. Clima României. Academia Română, București, Romania. 316 pp.

Andronache I, Fensholt R, Ahammer H, Ciobotaru A-M, Pintilii R-D, Peptenatu D, Drăghici C-C, Diaconu DC, Radulović M, Pulighe G, et al., 2017. Assessment of textural differentiations in forest resources in Romania using fractal analysis. Forests 8(3): 54-74. https://doi. org/10.3390/f8030054

Balboa-Murias MA, Rojo A, Álvarez JG, Merino A, 2006. Carbon and nutrient stocks in mature Quercus robur L. stands in NW Spain. Ann Forest Sci 63(5): 557565. https://doi.org/10.1051/forest:2006038

Bässler C, Müller J, Dziock F, Brandl R, 2010. Effects of resource availability and climate on the diversity of wood-decaying fungi. J Ecol 98: 822-832. https://doi.or$\mathrm{g} / 10.1111 / \mathrm{j} .1365-2745.2010 .01669 . \mathrm{x}$

Berbeco MR, Melillo JM, Orians CM, 2012. Soil warming accelerates decomposition of fine woody debris. Plant Soil 356: 405-417. https://doi.org/10.1007/s11104012-1130-x

Bernicchia A, 2005. Fungi Europaei. Polyporaceae s.1. Candusso, Alassio, Italy. 808 pp.

Bîrsan C, Tănase C, Mardari C, Cojocariu A, 2014. Diversity and ecological determinants of dead wood fungi in tree natural reserves of broad leaved forests from Suceava county. J Plant Develop 21: 153-160.

Boddy L, 1993. Saprotrophic cord-forming fungi: warfare strategies and other ecological aspects. Mycol Res 97(6): 641-655. https://doi.org/10.1016/S09537562(09)80141-X

Brazee NJ, Lindner DL, D'Amato AW, Fraver S, Forrester JA, Mladenoff DJ, 2014. Disturbance and diversity of wood-inhabiting fungi: effects of canopy gaps and downed woody debris. Biodivers Conserv 23: 2155-2172. https://doi.org/10.1007/s10531-014-0710-x

Breitenbach J, Kränzlin F, 1986. Champignons de Suisse. Tome 2. Champignons sans lames. Mykologia Luzern, Lucerne, Switzerland. 412 pp.

Buée M, Maurice J-P, Zeller B, Andrianarisoa S, Ranger J, Courtecuisse R, Marçais B, Le Tacon F, 2011.
Influence of tree species on richness and diversity of epigeous fungal communities in a French temperate forest stand. Fungal Ecol 4(1): 22-31. https://doi.org/10.1016/j. funeco.2010.07.003

Burnham KR, Anderson DR., 2002. Model selection and multimodel inference - A practical information - theoretic approach. 2nd ed. Springer, New York, US. 488 pp.

Chaudhary A, Burivalova Z, Koh LP, Hellweg S, 2016. Impact of forest management on species richness: Global meta-analysis and economic trade-offs. Sci Rep 6: 23954. https://doi.org/10.1038/srep23954

Coates D, Rayner ADM, 1985. Fungal population and community development in cut beech logs. I. Establishment via the aerial cut surface. New Phytol 101(1): 153171. https://doi.org/10.1111/j.1469-8137.1985.tb02823.x

Conrad O, Bechtel B, Bock M, Dietrich H, Fischer E, Gerlitz L, Wehberg J, Wichmann V, Böhner J, 2015. System for Automated Geoscientific Analysis (SAGA) v. 2.1.4. Geosci Model Dev 8: 2272-2312. https://doi. org/10.5194/gmdd-8-2271-2015

Copoț O, Balaeș T, Bîrsan C, Petre CV, Cojocariu A, Tănase C, 2018. Climatic predictors influences VFWD fungal diversity through dominant tree' ecology in beech forests in the North-Eastern Romania. J Plant Develop 25: 119-134. https://doi.org/10.33628/jpd.2018.25.1.119

Copoț O, Tănase C, 2019. Dead wood, forest fragmentation and elevation influences macrofungal diversity on downed coarse woody debris in beech and oak old forest ecosystems from Northeastern Romania. J Plant Develop 26:161-172. https://doi.org/10.33628/jpd.2019.26.1.161

Courtecuisse R, Duhem B, 2013. Champignons de France et d'Europe. Delachaux et Niestlé, Paris, France. 542 pp.

Dvořák D, Vašutová J, Hofmeister J, Beran M, Hošek J, Běták J, Burel J., Deckerová H, 2017. Macrofungal diversity patterns in central European forests affirm the key importance of old-growth forests. Fungal Ecol 27: 145154. https://doi.org/10.1016/j.funeco.2016.12.003

Eurostat, 2019. Your key to European statistics. http://ec.europa.eu/eurostat/web/regions/data/database/

Ellis JB, Everhart DM, 1966. The North American Pyrenomycetes. A contribution to mycologic botany. Johnson Reprint Corporation, New York, US. 793 pp.

Enrong Y, Xihua W, Jianjun H, 2006. Concept and classification of coarse woody debris in forest ecosystems. Front Biol 1(1): 76-84. https://doi.org/10.1007/ s11515-005-0019-y

Feurdean A, Wohlfarth B, Björkman L, Tantau I, Bennike O, Willis KJ, Farcaș S, Robertsson AM, 2007. The influence of refugial population on Lateglacial and early Holocene vegetational changes in Romania. Rev Palaeobot Palyno 145: 305-320. https://doi.org/10.1016/j. revpalbo.2006.12.004

Fick SE, Hijmans RJ, 2017. Worldclim 2: New 1-km spatial resolution climate surfaces for global land areas. Int J Climatol 37(12): 4302-4315. https://doi.org/10.1002/joc.5086 
Fyfe RM, Woodbridge J, Roberts N, 2015. From forest to farmland: pollen-inferred land cover change across Europe using the pseudobiomization approach. Global Change Biol 21(3): 1197-1212. https://doi.org/10.1111/ gcb. 12776

Führer E, Horváth L, Jagodics A, Machon A, Szabados I, 2011. Application of new aridity index in Hungarian forestry practice. Idojaras 115(3): 205-216.

Goia I, Gafta D, 2018. Beech versus spruce dead wood as forest microhabitat: does it make any difference to bryophytes? Plant Biosyst 153(2): 187-194. https://doi.org/ 10.1080/11263504.2018.1448011

Gora EM, Battaglia LL, Schumacher HB, Carson WP, 2014. Patterns of coarse woody debris volume among 18 late-successional and mature forest stands in Pennsylvania. J Torrey Bot Soc 141(2): 151-160. https:// doi.org/10.3159/TORREY-D-13-00066.1

Grünewald T, Bühler Y, Lehning M, 2014. Elevation dependency of mountain snow depth. Cryosphere 8: 2381-2394. https://doi.org/10.5194/tc-8-2381-2014

Hallett JG, Lopez T, O'Connell MA, Borysewicz MA, 2001. Decay dynamics and avian use of artificially created snags. Northwest Sci 75(4): 378-386.

Heilmann-Clausen J, Christensen M, 2003. Fungal diversity on decaying beech logs. implications for sustainable forestry. Biodivers Conserv 12: 953-973. https://doi. org/10.1023/A:1022825809503

Heilmann-Clausen J, Christensen M, 2004. Does size matter?: On the importance of various dead wood fractions for fungal diversity in Danish beech forests. Forest Ecol Manag 201(1): 105-117. https://doi.org/10.1016/ S0378-1127(04)00519-5

Heilmann-Clausen J, Aude E, Christensen M, 2005. Cryptogam communities on decaying deciduous wood - does tree species diversity matter? Biodivers Conserv 14:2061-2078. https://doi.org/10.1007/s10531-004-4284-X

Holloway GL, Caspersen JP, Vanderwel MC, Naylor BJ, 2007. Cavity tree occurrence in hardwood forests of central Ontario. Forest Ecol Manag 239(1-3):191-199. https://doi.org/10.1016/j.foreco.2006.12.004

Hottola J, Siitonen J, 2008. Significance of woodland key habitats for polypore diversity and red-listed species in boreal forests. Biodivers Conserv 17:2559-2577. https://doi.org/10.1007/s10531-008-9317-4

Index Fungorum, 2019. http://www.indexfungorum. org/Names/Names.asp

Iršènaitė R, Kutorga E, 2006. Diversity of fungi on decaying common oak coarse woody debris. Ekologija 4: 22-30.

Kebli H, Brais S, Kernaghan G, Drouin P, 2012. Impact of harvesting intensity on wood-inhabiting fungi in boreal aspen forests of Eastern Canada. Forest Ecol Manag 279: 45-54. https://doi.org/10.1016/j.foreco.2012.05.028

Klockow PA, D'Amato AW, Bradford JB, Fraver S, 2014. Nutrient concentrations in coarse and fine woody debris of Populus tremuloides Michx.-dominated forests, northern Minnesota, USA. Silva Fenn 48(1): 962. https:// doi.org/10.14214/sf.962

Kubart A, Vasaitis R, Stenlid J, Dahlberg A, 2016. Fungal communities in Norway spruce stumps along a latitudinal gradient in Sweden. Forest Ecol Manag 371: 50-58. https://doi.org/10.1016/j.foreco.2015.12.017

Kubartová A, Ranger J, Berthelin J, Beguiristain T, 2009. Diversity and decomposing ability of saprophytic fungi from temperate forest litter. Environ Microbiol 58: 98-107. https://doi.org/10.1007/s00248-008-9458-8

Kutsegi G, Siller I, Dima B, Takács K, Merényi Z, Varga T, Turcsányi G, Bidló A, Ódor P, 2015. Drivers of macrofungal species composition in temperate forests, West Hungary: functional groups compared. Fungal Ecol 17: 69-83. https://doi.org/10.1016/j.funeco.2015.05.009

LifeWatch Belgium, 2019. http://www.lifewatch.be/ en/data/

Lombardi F, Cherubini P, Tognetti R, Cocozza C, Lasserre B, Marchetti M, 2013. Investigating biochemical processes to as-sess dead wood decay of beech and silver fir in Mediterranean mountain forests. Ann Forest Sci 70: 101-111. https://doi.org/10.1007/s13595-012-0230-3

Méndez-Toribio M, Meave JA, Zermeño-Hernández I, Ibarra-Manríquez G, 2016. Effects of slope aspect and topographic position on environmental variables, disturbancce regime and tree community attributes in a seasonal tropical dry forest. J Veg Sci 27(6): 085002. https:// doi.org/10.1111/jvs.12455

Milescu I, Alexe A, Nicovescu H, Suciu P, 1967. Fagul. Ed. Agro-Silvică, București, Romania. 581 pp. [In Romanian]

Morrissey RC, Jenkins MA, Saunders MR, 2014. Accumulation and connectivity of coarse woody debris in partial harvest and unmanaged relict forests. PLoS One 9(11): e113323. https://doi.org/10.1371/journal. pone. 0113323

Ostrogović MZ, Marjanović H, Balenović I, Sever K, Jazbec A, 2015. Decomposition of fine woody debris from main tree species in lowland oak forests. Pol J Ecol 63(2): 247-259. https://doi.org/10.3161/15052249PJE2015.63.2.008

Nordén B, Götmark F, Tönnberg M, Ryberg M, 2004. Dead wood in semi-natural temperate broadleaved woodland: contribution of coarse and fine dead wood, attached dead wood and stumps. Forest Ecol Manag 194(1-3): 235-248. https://doi.org/10.1016/j.foreco.2004.02.043

Ódor P, Heilmann-Clausen J, Christensen M, Aude E, van Dort KW, Piltaver A, Siller I, Veerkamp MT, Walleyn R, Standovár T, et al., 2006. Diversity of dead wood inhabiting fungi and bryophytes in semi-natural beech forests in Europe. Biol Conserv, 131(1): 58-71. https://doi. org/10.1016/j.biocon.2006.02.004

Paliwal R, Giri K, Rai JPN, 2015. Microbial Lignolysis: Avenue for Natural Ecosystem Management. In: 
Handbook of Research on Uncovering New Methods for Ecosystem Management through Bioremediation; Singh S, Srivastana K (eds). pp: 120-144. Information Science Reference, Hershey, US. https://doi.org/10.4018/978-14666-8682-3.ch006

Perry RW, Thill RE, 2013. Comparison of snag densities among regeneration treatments in mixed pine-hardwood forests. Can J Forest Res 43(7): 619-626. https:// doi.org/10.1139/cjfr-2013-0005

Petritan AM, Biriș IA, Merce O, Turcu DO, Petritan IC, 2012. Structure and diversity of a natural temperate sessile oak (Quercus petraea L.) - European Beech (Fagus sylvatica L.) forest. Forest Ecol Manag 280: 140-149. https://doi.org/10.1016/j.foreco.2012.06.007

Preikša Z, Brazaitis G, Marozas V, Jaroszewicz B, 2015. Dead wood quality influences species diversity of rare cryptogams in temperate broadleaved forests. iForests 9: 276-285. https://doi.org/10.3832/ifor1483-008

Quan C, Han S, Utescher T, Zhang C, Liu YSC, 2013. Validation of temperature-precipitation based aridity index: Paleoclimatic implications. Paleogeogr Paleocl 386: 86-95. https://doi.org/10.1016/j.palaeo.2013.05.008

R Core Team, 2018. R: A language and environment for statistical computing. http://www.R-project.org/

Rabinowitsch-Jokinen R, Vanha-Majamaa I, 2010. Immediate effects of logging, mounding and removal of logging residues and stumps on coarse woody debris in managed Boreal Norway spruce stands. Silva Fenn 44(1): 51-62. https://doi.org/10.14214/sf.162

Roth TR, Nolin AW, 2017. Forest impacts on snow accumulation and ablation across an elevation gradient in a temperate montane environment. Hydrol Earth Syst Sc 21: 5427-5442. https://doi.org/10.5194/hess-21-5427-2017

Rudolph S, Maciá-Vicente JG, Lotz-Winter H, Shcleuning M, Piepenbring M, 2018. Temporal variation of fungal diversity in a mosaic landscape in Germany. Studi Mycol 89:95-104. https://doi.org/10.1016/j.simyco.2018.01.001

Runnel K, Lõhmus A, 2017. Dead wood-rich managed forests provide insights into the old-forest association of wood-inhabiting fungi. Fungal Ecol 27(Part B): 155-167. https://doi.org/10.1016/j.funeco.2016.09.006

Ryvarden L, 1976. The Polyporaceae of North Europe. vol. 1. Albatrellus - Incrustoporia. Fungiflora, Oslo, Norway. 214 pp.

Ryvarden L, 1991. Genera of Polypores. Nomenclature and taxonomy. Synopsis Fungorum Series 5, Fungiflora, Oslo, Norway. 363 pp.

Ryvarden L, Gilbertson RL, 1994. European Polypores. Part 2. Meripilus - Tyromyces. Oslo, Fungiflora, Norway. 743 pp.

Schall P, Ammer C, 2013. How to quantify forest management intensity in Central European forests. Eur J Forest Res 132(2): 379-296. https://doi.org/10.1007/s10342013-0681-6
Sefidi K, Etemad V, 2015. Dead wood characteristics influencing macrofungi species abundance and diversity in Caspian natural beech (Fagus orientalis Lipsky) forests. Forest Syst 24(2): eSC03. https://doi.org/10.5424/ fs/2015242-06039

Sippola A-L, Similä M, Mönkkönen M, Jokimäki J, 2004. Diversity of polyporous fungi (Polyporaceae) in northern boreal forests: effects of forest site type and logging intensity. Scand J Forest Res 19(2): 152-163. https:// doi.org/10.1080/02827580410026294

Tavankar F, Picchio R, Lo Monaco A, Bonyad AE, 2014. Forest management and snag characteristics in Northern Iran lowland forests. J For Sci 60(10): 431-441. https://doi.org/10.17221/77/2014-JFS

Tavankar F, Nikooy M, Picchio R, Venanzi R, Lo Monaco A, 2017. Long-term effects of single-tree selection cutting management on coarse woody debris in natural mixed beech stands in the Caspian forest (Iran). iForest 10(3): 652-658. https://doi.org/10.3832/ifor2091-010

Tănase C, Bîrsan C, Chinan V, Cojocariu A, 2009. Macromicete din România. Universitatea Alexandru Ioan Cuza, Iaşi, Romania. 564 pp. [In Romanian]

Tedersoo L, Bahram M, Põlme S, Kõljalg U, Yorou NS, Wijesundera R, Ruiz LV, Vasco-Palacios AM, Thu PQ, Suija A, et al., 2015 Global diversity and geography of soil fungi. Science 346(6213): 1256688. https://doi. org/10.1126/science. 1256688

Unar P, Janík D, Adam D, Vymazalová M, 2017. The colonization of decaying logs by vascular plants and the consequences of fallen logs for herb layer diversity in a lowland alluvial forest. Eur J Forest Res 136(4): 665-676. https://doi.org/10.1007/s10342-017-1063-2

Unterseher M, Otto P, Morawetz W, 2003. Studies of the diversity of lignicolous fungi in the canopy of a floodplain forest in Leipzig, Saxony. Boletus 26(2): 117-126.

van der Wal A, Gunnewiek PK, de Hollander M, de Boer W, 2017. Fungal diversity and potential tree pathogens in decaying logs and stumps. Forest Ecol Manag 406: 266-273. https://doi.org/10.1016/j.foreco. 2017.08.018

Wirth C, Messier C, Bergeron Y, Frank D, Fankhänel A, 2009. Chapter 2: Old-growth forest definitions: a pragmatic view. In: Old-Growth Forests. Ecological Studies (Analysis and Synthesis), Vol. 207; Wirth C, Gleixner G, Heimann M. (eds). pp: 11-33. Springer, Berlin, Germany. https://doi.org/10.1007/978-3-540-92706-8_2

Wisdom MJ, Bate LJ, 2008. Snag density varies with intensity of timber harvest and human access. Forest Ecol Manag 255(7): 2085-2093. https://doi.org/10.1016/j.foreco.2007.12.027

Woodall CW, Liknes GC, 2008. Climatic regions as an indicator of forest coarse and fine woody debris carbon stocks in the Unites States. Carbon Balance and Manag 3(1): 1-8. https://doi.org/10.1186/1750-0680-3-5 